\title{
Species Richness and Seasonal Activity of the Leaf Cutter and Resin Bees (Hymenoptera: Megachilidae) at Pantnagar
}

\author{
Neha Kunjwal ${ }^{1}$, M. S. Khan ${ }^{2}$, Poonam Srivastava ${ }^{3}$ \\ Department of Entomology, College of Agriculture, G. B. Pant University of Agriculture and Technology, Pantnagar - 263145 \\ (U. S. Nagar, Uttarakhand) India
}

\begin{abstract}
The investigation on diversity, species richness and seasonal activity of the native megachilid bees carried out in different ecosystems during March, 2013 to April, 2015 at Pantnagar revealed occurrence of 19 species including 7 leaf cutter bees (Megachile albifrons, M. anthracena, M. bicolor, M. chlorigaster, M. conjuncta, M. relata, M. studiosa), 5 resin bees (M. cephalotes, , M. disjuncta, M. hera, M. inepta, M. lanata, M. umbripennis) and 7 other species viz. M. binghami, , M. elizabathae, M. femorata, M. gathela, M. rajasthaniensis and M. tetradenta. Our results show that species richness of megachilid bees was maximum in the month of April (18 species) followed by March and May, and October- November when 10-11 species were recorded in the field. About 58 percent of the total species had two peaks of their activity with 2-3 generations in a year. Minimum activity of species of megachilid bees was recorded during Dec- Feb (0-5 species; winter season) and July-Sept (2-4 species; rainy season). The resin bees, M. cephalotes and M. disjuncta were mulitivoltine in nature and were active almost throughout the year. Effect of abiotic factors on the seasonal activity of the native megachilid bees has also been discussed.
\end{abstract}

Keywords: megachilid bees/ solitary bees/ diversity/ species richness/ seasonal activity

\section{Introduction}

Pollinators carry pollen from the male to the female parts of plants that leads to seed formation and thus supports agricultural diversity. $87 \%$ of all flowering plants are animal pollinated [1] and globally, honey bees, bumble bees and solitary bees are considered to be the most important group of pollinators, contribute $35 \%$ of the world's food production [2]. Solitary bees of the family Megachilidae have excellent anatomical and behavioral adaptations and thus work as effective pollinators for many agricultural important crops [3]. Urbanization, use of pesticides and pests are major causes of native and managed pollinator's decline [4], raising concerns about a pollination crisis of wild plants and crops. Greater diversity of bee species resulted in higher seed production [5] and can help to meliorate the loss of important species [6]. To prevent pollinator decline it is necessary to find out the factors that influence species richness and their abundance in a wide range of habitats [7]. Megachilidae is the second largest bee family, containing more than 4000 described species in a wide diversity of habitats on all continents except Antarctica, ranging from lowland tropical rain forests to deserts and alpine environments [8, 9]. 500-600 species of megachilid bees in India were reported earlier [10] from which $M$. bicolor, M. lanata, M. cephalotes, M. albifrons and $M$. disjuncta are recorded in northern half of the country in Eastern Rajasthan, U. P. [11] and Uttarakhand [12].

Bees contribute significantly to the income for farmers by increasing yields in horticultural crops, seeds and graze through better conservation and management of pollinators. Their conservation implies the interactions between species conservation and careful management, to strengthen ecosystem linkages, sustainable production systems and poverty reduction. A few megachilid bee species such as Megachile rotundata and Osmia species now have been developed as managed pollinators in European countries but still the lack of information on diversity and life history of most megachilid bee species affect their successful use in the management of crops. Studies on the diversity, species richness and abundance of bee pollinators are of vital importance to know their ethology, ecology, biology, improve reproduction success in plant communities and for their conservation and management [13]. With a view to document diversity, species richness and seasonal activity of native megachilid bees, systematic studies were conducted to know the pollinator fauna of the region.

\section{Material and Methods}

This study was carried out from March 2013 to April 2015 at Govind Ballabh Pant University of Agriculture and Technology Pantnagar, at an altitude of 243.84 meters above sea level, latitude $29^{\circ} \mathrm{N}$ and longitude $79.3^{\circ} \mathrm{E}$. This location is situated in the foot hills of Shivalik range of Himalayas. The humid sub tropical climate here is characterized by hot dry summer and cold winter. The temperature rises up to $40^{\circ} \mathrm{C}$, while it falls to $4^{0} \mathrm{C}$ in winter. Rainfall has been recorded with an average precipitation of $136 \mathrm{~cm}$ and relative humidity fluctuates around $90 \pm 5$ percent (at 7:00 am) during rainy season. The study area has rich floral diversity with more than 800 plant species.

To explore the diversity of megachilid bees, we used two approaches: (i) regular surveys at 15 days interval were conducted in the various ecosystems at different research centres of the University campus. These centre included Normen E. Borloug -Crop Research Centre, Vegetable Research Centre, Garden Section, Model Floriculture Research Centre, Agro Forestry Research Centre, University Apiary, Model Bee Research and Training Centre etc. The megachilid bees found foraging on the flowers and also on other substrates were collected with the help of sweep net or 


\section{International Journal of Science and Research (IJSR) \\ ISSN (Online): 2319-7064 \\ Index Copernicus Value (2013): 6.14 | Impact Factor (2015): 6.391}

directly in insect killing jar. (ii) Provided nesting avenues in the form of tunnels in wooden structures and one end open bamboo canes. For this, nesting wood shelters (Bee Post and Triangular Bee Nesting Shelter) were designed and installed at various locations namely Norman E. Borlaug Crop Research Centre, Garden Section, University Apiary and Model Floriculture Research Centre in March, 2013. Nesting Bee Post (modified from [14, 15]) had 5.5 feet wooden pole in the centre fitted with four wooden arms of $100 \mathrm{~mm}$ thickness on each side with holes of 85 to $92 \mathrm{~mm}$ having diameters of 5 $-6 \mathrm{~mm}$ on one side arms and $9-10$ $\mathrm{mm}$ holes on other side arms were made by drilling machine at a distance of $20 \times 20 \mathrm{~mm}$. In one Bee Post $274-327$ nesting tunnels were provided to ensure more nesting shelters at one place. The other shelter, named as Triangular Bee Nesting Shelter (modified from $[16,17]$ ) with hollow tunnels of various diameters ranging from $3.0-9.0 \mathrm{~mm}$ having tunnel length 100 and $250 \mathrm{~mm}$ were placed in groups of 25-30 sticks. The nest constructed by megachilid bees in these tunnels were marked during regular survey visits. After completion of the nest making activity, the nests were covered with glass vials till the emergence of adult bees. All the specimens, collected from sweep net and nest shelters were pinned with entomological needles and preserved in the Apiculture laboratory for further taxonomic identification. Individuals of native megachilid bees collected were got identified to species from Department of Zoology, Jai Narayan Vyas Krishi Vishwa Vidhalaya, Jodhpur (Rajasthan). Identification of the plant species was confirmed from the Department of Biological Sciences of this university.

The seasonal activity of various species of native megachilid bees was recorded during regular site visits at 15 days interval. The species, thus observed in the field during visits was considered as active.

\section{Results and Discussion}

\section{Diversity of megachilid bees}

A total of 19 species, all belonging to genus Megachile recorded in the study area during investigation period (Table 1) were: Megachile albifrons, M. anthracena, M. bicolor, $M$. binghami, M. cephalotes, $M$. chlorigaster, M. conjuncta, $M$. disjuncta, M. elizabathae, M. femorata, M. gathela, M. hera, $M$. inepta, $M$. lanata, $M$. rajasthaniensis, $M$. relata, $M$. studiosa, M. tetradenta, and M. umbripennis. Among these, M. albifrons, M. anthracena, M. bicolor, M. chlorigaster, $M$. conjuncta, $M$. relata and $M$. studiosa were the leaf cutter bees and $M$. cephalotes, $M$. disjuncta, M. inepta, M. lanata and M. umbripennis were observed as resin/mason bees. Remaining 7 species could not be categorised either as leaf cutter or as resin/mason bees since we had not observed their nest structure or the nesting resources during observation period of this study. Neither the available literature speaks about the nesting biology and other ecological parameters of these megachilid bee species. 9 genera with 57 species belonging to the Megachilidae family were reported earlier [18] from Uttarakhand, India. Our results on diversity indicated that this area has good potential to harbour great bee diversity owing its rich floral diversity and climate. The pollinator bees have particular profile of diversity and species richness [8] that strongly affected by resource availability $[19,20,21]$, extent and proximity of the surrounding habitat $[22,23]$ and abiotic factors. Other studies also concluded that where there is great plant diversity, there is great bee diversity [24, 25].

\section{Seasonal activity and species richness of megachilid bees}

The data recorded on the activity of megachilid bees revealed that these bees were active throughout the year except in the month of Febuary when no Megachilid species was found in the field during observation days (Table1). The data further revealed that among the 19 species recorded in the field, only two species, $M$. cephalotes and $M$. disjuncta were consistently active round the year. The species richness of megachilid bees varied in different months of the year (Table 1; Fig 2). Maximum number (18) of the Megachilid species was recorded in the month of April followed by in the months of March and May, and October- November when 10-11 species were recorded in the field (Fig 2). The matrix of seasonal activity of megachilid bees (Table 1; Fig 3) also showed that most of the species recorded had two peaks of their activity, first in the months of March to May when mean maximum and minimum temperature and $\mathrm{RH} \%$ (2.00 pm) varied from $27.4{ }^{0} \mathrm{C}$ to $38.9{ }^{\circ} \mathrm{C}, 13.0{ }^{\circ} \mathrm{C}$ to $23.4{ }^{\circ} \mathrm{C}$ and $26 \%$ to $44 \%$ and second in the months of OctoberNovember when mean maximum and minimum temperature and $\mathrm{RH} \%$ (2.00 pm) varied from $26.9{ }^{\circ} \mathrm{C}$ to $30.4{ }^{0} \mathrm{C}, 10.2{ }^{\circ} \mathrm{C}$ to $19.8{ }^{\circ} \mathrm{C}$ and $40 \%$ to $59 \%$, respectively. It also appeared that higher relative humidity adversely affect the activity of megachilid bees (Fig 3). Minimum activity and minimum number of species of megachilid bees was recorded during winter season (Dec- Feb; 0-5 species) and the rainy season (July- Sept; 2-4 species). Also, the activity of Megachile nana and Megachile flavipes on alfalfa was studied [26] and positively correlated with environmental factors (air temperature, light intensity and solar radiation) and nectar sugar concentration. Species and population abundance of solitary bees have reported to vary from season to season and region to region over the years [8]. The bees of Megachilidae family are favoured by warm climates; however, they are still active in cool days and frequent during the blooming period [3]. Among various species of megachilid bees that had their first activity peak in the month of April (18 species), 11 species namely $M$. anthracena, M. bicolor, M. cephalotes, M. chlorigaster, $M$. conjuncta, $M$. disjuncta, $M$. hera, M. lanata, $M$. rajasthaniensis, $M$. relata and $M$. umbripennis were found again active in the months of October- November. This indicated that these 11 species have 2-3 generations in a year. Megachile bees flies during the warmest parts of the year, with 2-4 generations per year [8], depending on locality and resources. Among these 18 species, $M$. cephalotes and $M$. disjuncta were mulitivoltine in nature since they were active almost throughout the year. Remaining 8 species studied for biological parameters during present investigation require more elaborate studies on their seasonal activity for determination of their voltinism

\section{Conclusion}

This study demonstrated that this region has rich diversity of Megachilid species and there is a need to conduct detailed investigation on various biological parameters for the 


\section{International Journal of Science and Research (IJSR) \\ ISSN (Online): 2319-7064 \\ Index Copernicus Value (2013): 6.14 | Impact Factor (2015): 6.391}

conservation and restoration of the diversity of these bees as a whole so that they can be more efficiently utilized as a supplement to other natural pollinating insects including honey bees and as an alternative pollination source in future to have a potential contribution in the pollination of wide range of economic important crops.

\section{Acknowledgement}

We are grateful to Dr. Rajiv K. Gupta, Professor, Department of Zoology, JNVU, Jodhpur for confirmation of bee species and Dr. D. S. Rawat, Associate Professor, Biological Sciences G.B.P.U.A. \& T. Pantnagar for identifying plant species.

\section{References}

[1] Ollerton J, Winfree R, Tarrant S (2011) How many flowering plants are pollinated by animals? Oikos 120: 321-326.

[2] Das B, Ahmad N, Srivastava, KK, Ranjan, P (2011) Top working method and bloom density of pollinizers as productive determinant for spur type apple (Malus x domestica Borkh.) cultivars. Sci Hort 129: 642-648.

[3] Felicioli A, Pinzauti M (2008) Pollination by Osmia bees (Hymenoptera: Megachilidae), In JL Capinera [2 ${ }^{\text {nd }}$ ed.], Encyclopedia of Entomology, Springer 4346 p.

[4] Jones EL, Leather SR (2012) Invertebrates in urban areas: a review. Eur J Entomol 109: 463-478.

[5] Frund J, Dormann CF, Holzschuh A, Tscharntke T (2013) Bee diversity effects on pollination depend on functional complementarity and niche shifts. Ecology 94 (9): 2042-2054.

[6] Laliberte E, Wells JA, DeClerck F, Metcalfe DJ, Catterall CP, Queiroz C, Aubin I, Bonser SP, Ding Y, Fraterrigo JM, McNamara S, Morgan JW (2010) Landuse intensification reduces functional redundancy and response diversity in plant communities. Ecol Lett 7686.

[7] Williams NM, Crone EE, Roulston TH, Minckley RL, Packer L, Potts, SG (2010) Ecological and life-history traits predict bee species responses to environmental disturbances. Biol Conserv 143 (10): 2280-2291.

[8] Michener CD (2007) The Bees of the world. $2^{\text {nd }}$ ed. The Johns Hopkins Univ. Press, Baltimore. 992 p.

[9] Ascher J, Pickering J (2011) Bee species guide (Hymeoptera: Apoidea). Ann RevEntomol 56: 221-237.

[10] Gupta RK (1993) Taxonomic studies on the Megachilidae of north-western India. Scientific Publishers, India. 294 p.

[11]Gupta RK, Yadav S (2001) Apoidean species composition on Crotalaria juncea L., Cajanus cajan (L.), Helianthus annus L., and Brassica campestris L. var sarson Prain in eastern Rajasthan, India (Hymenoptera). Opuscula zoological fluminensia 198:1-10
[12]Khan MS, Srivastava P (2013) Insect pollinators and crop pollination: Research Bulletin. Directorate of Experiment station, G.B. Pant University of Agriculture $\&$ Technology, Pantnagar $70 \mathrm{p}$.

[13] Purvis A, Hector A (2000) Getting the measure of biodiversity. Nature 405: 212-219.

[14] Barthell JF, Gordon WF, Thorp RW (1998) Invader effects in a community of cavity nesting Megachilid bees (Hymenoptera: Megachildae). Environ Entomol 27 (2): 240-247.

[15]Zillikens A, Steiner J (2004) Nest architecture, life cycle and cleptoparasite of the Neotropical leaf cutting bee Megachile (Chrysosarus) pseudanthidioides Moure (Hymenoptera: Megachile). J Kans Entomol Soc 77 (3):193-202.

[16] Chaudhary J R, Jain K L (1978) Nesting and foraging behaviour of a mason bee Megachile lanata (Megachilidae: Hymenoptera). Indian J Entomol 40 (4): 405-411.

[17] Steffan- Dewenter I, Schiele S (2004) Nest site fidelity, body weight and population size of the red mason bee, Osmia rufa (Hymenoptera: Megachilidae), evaluated by mark recapture experiments. Entomologica Generalis 27: 123-131.

[18] Gupta RK (2013) Apoidea (Insecta: Hymenoptera) of Uttarakhand state (India): A check list with synonymies and distribution record. J of Environ Biosci. 27 (1): 57:70.

[19] Tonietto R, Fant J, Ascher J, Ellis K, Larkin, D (2011) A comparison of bee communities of Chicago green roofs, parks and prairies. Landscape Urban Planning. 103: 102-108.

[20] Roulston TH, Goodell K (2011) The role of resources and risks in regulating wild bee populations. Annu Rev Entomol 56: 293-312.

[21] Watson JC, Wolf AT, Ascher JS (2011) Forested landscapes promote richness and abundance of native bees (Hymeoptera: Apoidea: Anthophila) in Wisconsin apple orchards. Environ Entomol 40: 621-632.

[22] Sobek S, Tscharntke T, Scherber C, Schiele S, SteffanDewenter I (2009) Canopy vs. understory: Does tree diversity affect bee and wasp communities and their natural enemies across forest strata? Forest Ecol Mgt 258: 609-615.

[23] Hagen M, Kraemer M (2010) Agricultural surroundings support flower-visitor networks in an Afrotropical rain forest. Biol Conserv 143: 1654-1663.

[24] Hendrix SD, Kwaiser KS, Heard SB (2010) Bee communities (Hymenoptera: Apoidea) of small Iow hill prairies are as diverse and rich as those of large prairie preserves. Biodivers Conserv 19: 1699-1709.

[25] Wojcik V (2011) Resource abundance and distribution drive bee visitation within developing tropical urban landscapes. J Pollination Ecol 4 (7): 48-56.

[26] Abrol DP (1990) Pollination activity of alfalfapollinating subtropical bees Megachile nana and Megachile flavipes (Hymenoptera: Megachilidae). Trop Ecol 31 (1): 106-115. 


\section{International Journal of Science and Research (IJSR) \\ ISSN (Online): 2319-7064}

Index Copernicus Value (2013): 6.14 | Impact Factor (2015): 6.391

Table 1: Diversity and activity period of megachilid bees at Pantnagar

\begin{tabular}{|c|c|c|c|c|c|c|c|c|c|c|c|c|c|c|c|c|}
\hline \multirow[b]{2}{*}{ Megachilid species } & \multirow[b]{2}{*}{$\begin{array}{l}\text { Common } \\
\text { name }\end{array}$} & \multirow[b]{2}{*}{$\begin{array}{l}\text { Collection } \\
\text { month }\end{array}$} & \multirow[b]{2}{*}{$\begin{array}{l}\text { Collection } \\
\text { substrate }\end{array}$} & \multicolumn{12}{|c|}{ Activity period of megachilid bees in different months } & \multirow{2}{*}{$\begin{array}{c}\text { Total activity } \\
\text { period } \\
\text { observed } \\
\text { (months) }\end{array}$} \\
\hline & & & & Jan & Feb & Mar & April & May & June & July & Aug & Sept & Oct & Nov & Dec & \\
\hline $\begin{array}{c}\text { Megachile albifrons } \\
\text { Smith }\end{array}$ & $\begin{array}{c}\text { Leaf cutter } \\
\text { bee }\end{array}$ & April & $\begin{array}{l}\text { Justicia } \\
\text { flower }\end{array}$ & & & + & + & + & + & & & & & & & 4 \\
\hline $\begin{array}{c}\text { Megachile anthracina } \\
\text { Smith }\end{array}$ & $\begin{array}{c}\text { Leaf cutter } \\
\text { bee }\end{array}$ & Oct & $\begin{array}{l}\text { Pegion pea } \\
\text { flower }\end{array}$ & & & & + & + & & & & + & + & + & & 5 \\
\hline \begin{tabular}{|c|}
$\begin{array}{c}\text { Megachile bicolor } \\
\text { (Fabricius) }\end{array}$ \\
\end{tabular} & $\begin{array}{c}\text { Leaf cutter } \\
\text { bee }\end{array}$ & April & $\begin{array}{c}\text { Justicia } \\
\text { flower }\end{array}$ & & & + & + & + & & & & & + & + & + & 6 \\
\hline $\begin{array}{c}\text { M. binghami Meade } \\
\text { Waldo }\end{array}$ & - & April & $\begin{array}{l}\text { Blue cary } \\
\text { flower }\end{array}$ & & & & + & & & & & & & & & 1 \\
\hline $\begin{array}{c}\text { Megachile cephalotes } \\
\text { Smith } \\
\end{array}$ & $\begin{array}{c}\text { Resin/ } \\
\text { mason bee }\end{array}$ & Nov & $\begin{array}{l}\text { Mung } \\
\text { flower }\end{array}$ & & & + & + & + & + & + & + & + & + & + & + & 10 \\
\hline \begin{tabular}{|c|} 
Megachile \\
chlorigaster Cameron
\end{tabular} & $\begin{array}{c}\text { Leaf cutter } \\
\text { bee }\end{array}$ & Nov & $\begin{array}{l}\text { Gladium } \\
\text { flower }\end{array}$ & + & & + & + & & & & & & & + & + & 5 \\
\hline $\begin{array}{c}\text { Megachile conjuncta } \\
\text { Smith } \\
\end{array}$ & $\begin{array}{c}\text { Leaf cutter } \\
\text { bee }\end{array}$ & Sept & $\begin{array}{l}\text { Kachnar } \\
\text { leaf }\end{array}$ & & & + & + & & & & & + & + & + & & 5 \\
\hline $\begin{array}{c}\text { Megachile disjuncta } \\
\text { Fabricius }\end{array}$ & $\begin{array}{l}\text { Resin/ } \\
\text { mason bee }\end{array}$ & April & $\begin{array}{c}\text { White } \\
\text { Kachnar } \\
\text { flower } \\
\end{array}$ & + & & & + & + & + & + & + & + & + & + & + & 10 \\
\hline $\begin{array}{c}\text { Megachile } \\
\text { elizabathae Bingham }\end{array}$ & - & April & $\begin{array}{c}\text { Blue cary } \\
\text { flower }\end{array}$ & & & + & + & & & & & & & & & 2 \\
\hline $\begin{array}{c}\text { Megachile femorata } \\
\text { Smith }\end{array}$ & - & April & $\begin{array}{l}\text { Blue cary } \\
\text { flower }\end{array}$ & & & + & + & & & & & & & & & 2 \\
\hline $\begin{array}{c}\text { Megachile gathela } \\
\text { Cameron }\end{array}$ & - & April & $\begin{array}{l}\text { Blue cary } \\
\text { flower }\end{array}$ & & & & + & & & & + & & & & & 2 \\
\hline $\begin{array}{c}\text { Megachile hera } \\
\text { Bingham }\end{array}$ & - & April & $\begin{array}{c}\text { Dalbargia } \\
\text { flower }\end{array}$ & & & & + & + & & & & & + & + & & 4 \\
\hline $\begin{array}{c}\text { Megachile inepta } \\
\text { Cameron }\end{array}$ & $\begin{array}{c}\text { Resin } / \text { maso } \\
\mathrm{n} \text { bee }\end{array}$ & April & $\begin{array}{c}\text { Dalbargia } \\
\text { flower }\end{array}$ & & & & + & + & + & & & & & & & 3 \\
\hline $\begin{array}{c}\text { Megachile lanata } \\
\text { Fabricius }\end{array}$ & $\begin{array}{c}\text { Resin } / \text { maso } \\
\mathrm{n} \text { bee }\end{array}$ & March & $\begin{array}{c}\text { Nest in Bee } \\
\text { Post }\end{array}$ & & & + & + & & & & & & + & + & & 4 \\
\hline $\begin{array}{c}\text { Megachile } \\
\text { rajasthaniensis } \\
\text { Gupta }\end{array}$ & - & March & $\begin{array}{c}\text { Nest in Bee } \\
\text { Post }\end{array}$ & & & + & + & & & & & & + & + & & 4 \\
\hline $\begin{array}{c}\text { Megachile relata } \\
\text { Smith }\end{array}$ & $\begin{array}{c}\text { Leaf cutter } \\
\text { bee }\end{array}$ & Nov & $\begin{array}{c}\text { Gladium } \\
\text { flower }\end{array}$ & & & + & + & + & & & & & + & + & + & 6 \\
\hline $\begin{array}{c}\text { Megachile studiosa } \\
\text { Bingham }\end{array}$ & $\begin{array}{l}\text { Leaf cutter } \\
\text { bee }\end{array}$ & April & $\begin{array}{c}\text { Chasteberry } \\
\text { flower }\end{array}$ & & & & + & + & + & & & & & & & 3 \\
\hline $\begin{array}{c}\text { Megachile tetradenta } \\
\text { Gupta }\end{array}$ & - & May & $\begin{array}{c}\text { Marigold } \\
\text { flower }\end{array}$ & & & & & + & & & & & & & & 1 \\
\hline $\begin{array}{c}\text { Megachile } \\
\text { umbripennis Smith }\end{array}$ & $\begin{array}{c}\text { Resin } / \text { maso } \\
\mathrm{n} \text { bee }\end{array}$ & March & $\begin{array}{l}\text { Nest in } \\
\text { bamboo } \\
\text { sticks }\end{array}$ & & & + & + & & & & & & + & + & & 4 \\
\hline Total (19) & & - & - & 2 & - & 11 & 18 & 10 & 5 & 2 & 3 & 4 & 10 & 11 & 5 & \\
\hline
\end{tabular}

Volume 5 Issue 8, August 2016 www.ijsr.net

Licensed Under Creative Commons Attribution CC BY 
International Journal of Science and Research (IJSR)

ISSN (Online): 2319-7064

Index Copernicus Value (2013): 6.14 | Impact Factor (2015): 6.391

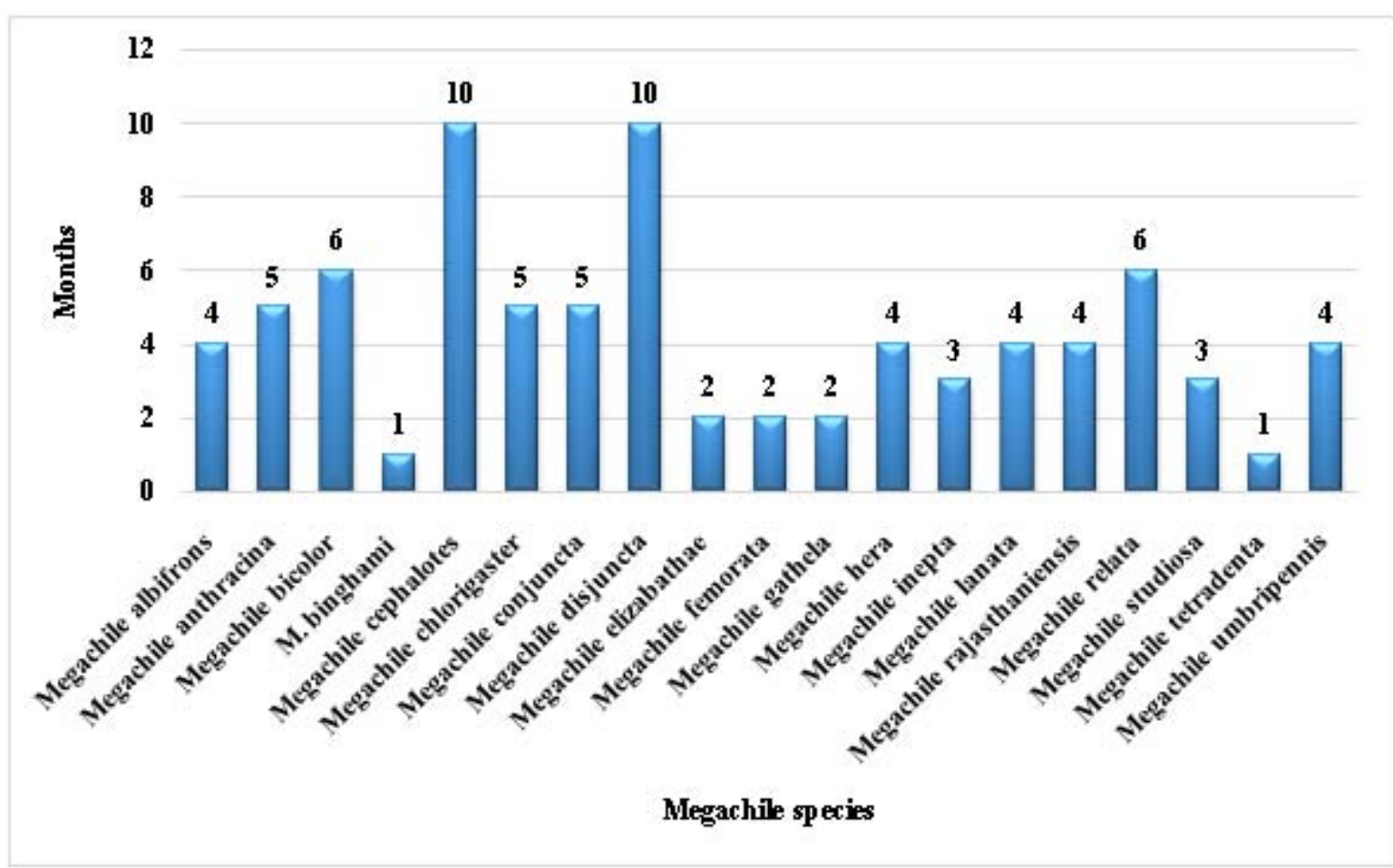

Figure 1: Activity period (in months) of different Megachile species at Pantnagar

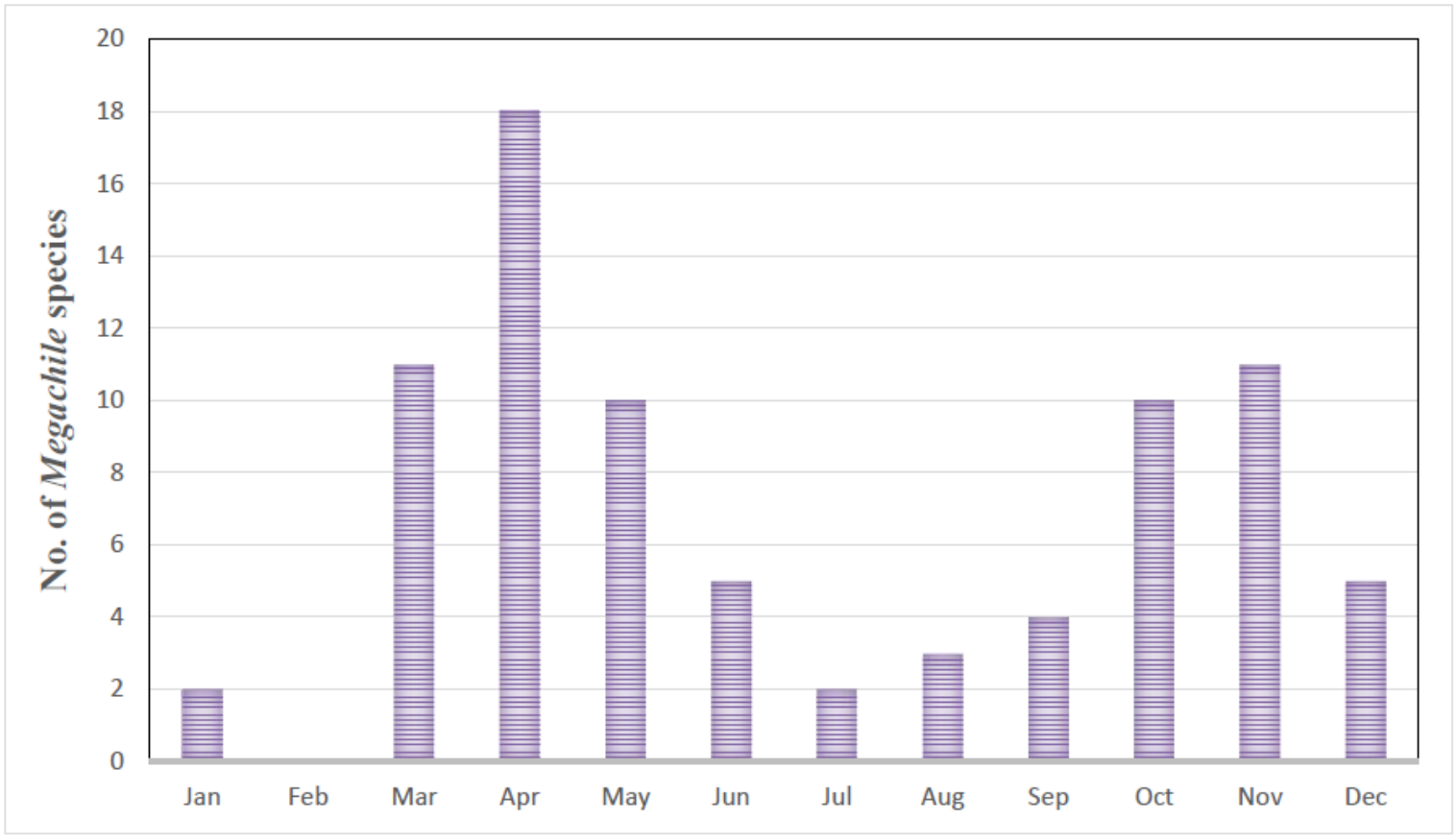

Figure 2: Species richness of Megachile bees during different months

Volume 5 Issue 8, August 2016 www.ijsr.net

Licensed Under Creative Commons Attribution CC BY 


\section{International Journal of Science and Research (IJSR)}

ISSN (Online): 2319-7064

Index Copernicus Value (2013): 6.14 | Impact Factor (2015): 6.391

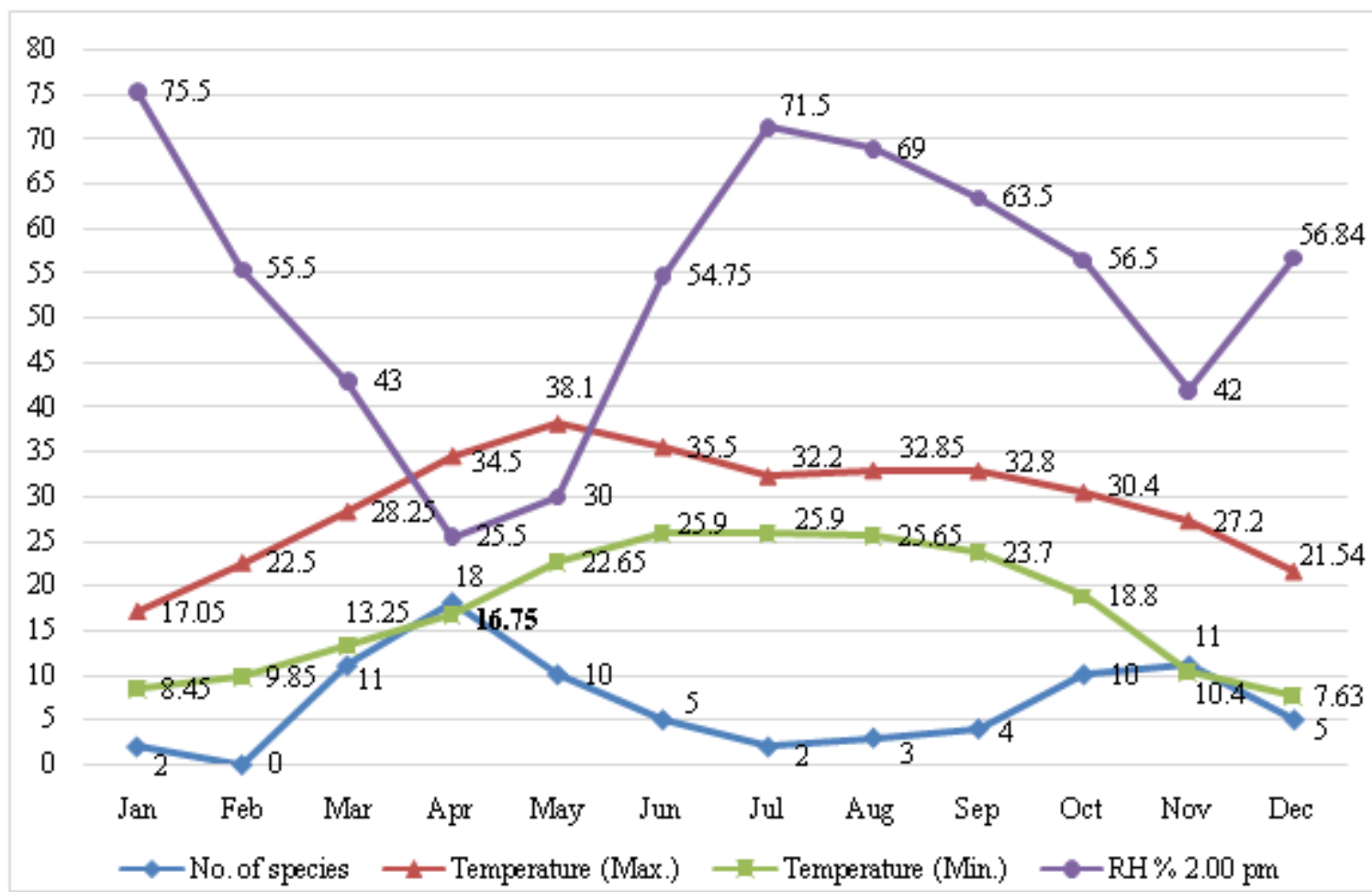

Figure 3: Species richness of Megachile species and their relation with abiotic factors during different months

Volume 5 Issue 8, August 2016 www.ijsr.net

Licensed Under Creative Commons Attribution CC BY 